\title{
Habitat-specific effects of interstitial space between stream substrate particles on the colonization of aquatic organisms
}

\author{
Takaharu Natsumeda $\odot$ - Kei'ichiro Iguchi
}

Received: 16 April 2019/Accepted: 19 October 2019/Published online: 5 November 2019

(C) The Author(s) 2019

\begin{abstract}
We examined the effects of interstitial space between stream substrate particles on the colonization of aquatic organisms using three types of substrates (gravel, a cobble, and a cobble on gravel) in a riffle and pool of a temperate stream. Significantly greater abundance, wet weight, diversity $\left(H^{\prime}\right)$, taxonomic richness, and evenness of aquatic organisms were found in the riffle than in the pool, and the interstitial space substrate (i.e., a cobble on gravel) had significantly greater abundance, wet weight, and taxonomic richness of aquatic organisms than did the cobble substrate. Of the 13 families observed in the experiments, larval net-spinning caddisfly (Hydropsychidae) dominated the riffle in terms of the abundance and wet weight; chironomid larvae dominated both the riffle and the pool in terms of abundance. Simple main effect tests indicated significant effects of substrate on the abundance and wet weight of larval caddisfly in the riffle, and post hoc tests on substrate in each habitat indicated that the abundance and wet weight of larval caddisfly on interstitial space substrate were significantly greater than those on cobble substrate in the riffle. Our results suggest the importance of interstitial space between stream substrates in riffles to ensure higher colonization rates of aquatic organisms such as larval net-spinning caddisflies characterized as filter feeders.
\end{abstract}

Keywords Aquatic organisms $\cdot$ Colonization $\cdot$ Interstitial space $\cdot$ Net-spinning caddisflies $\cdot$ Riffle $\cdot$ Substrate

\section{Introduction}

The asymmetric distribution of aquatic organisms can be interpreted as their response to habitat heterogeneity both in time and space. Running water sources, such as rivers and streams, are characterized as unique habitats with a high degree of spatial and temporal heterogeneity of the physical environment (e.g., temperature, current speed, water depths, and substrates) at all scales (Allan 1995; Giller and Malmqvist 1998). Such environmental heterogeneity in running water often provides habitat complexity, which allows the distribution of a variety of aquatic organisms in lotic ecosystems (Ward 1992; Vinson and Hawkins 1998).

Substrate has been suggested as a primary organizing variable for assemblages of aquatic organisms (Peckarsky 1986; Ward 1992; Allan 1995; Williams and Smith 1996). Substrate structural complexity, such as

T. Natsumeda $(\bowtie)$

College of Education, Ibaraki University, 2-1-1 Bunkyo, Mito, Ibaraki 310-8512, Japan

e-mail: takaharu.natsumeda.ecol@vc.ibaraki.ac.jp

K. Iguchi

Graduate School of Fisheries Science and Environmental Studies, Nagasaki University, 1-14 Bunkyo-cho, Nagasaki 852-8521, Japan 
surface complexity, substrate particle size, and submerged logs on the streambed, have been widely accepted as one of the most important determinants of the colonization and taxa richness of aquatic organisms in lotic ecosystems (Hart 1978; Erman and Erman 1984; O'Connor 1991; Downes and Jordan 1993; Vinson and Hawkins 1998).

Interstitial space, present between substrate particles on the streambed, is also considered an indicator of substrate structural complexity for aquatic organisms (Minshall 1984; Peckarsky 1986); however, the availability of such interstitial space in stream environments would be substantially different between channel unit habitats. In riffles with faster current velocities, the underside of pebbles or cobbles on the streambed often provides interstitial space that can be colonized by aquatic organisms such as net-spinning organisms (Wallace and Merritt 1980; Georgian and Thorp 1992); however, in pools with slower current velocities, pebbles and cobbles are often embedded entirely into the streambed and interstitial space is not readily available for aquatic organisms such as Neoperla (Plecoptera) and Hydropsyche and Setodes (Trichoptera) (Hamid and Rawi 2011). Thus, the complex features of flow and substrate composition in riffles and pools are so closely interrelated that under natural conditions it is often impossible to separate the individual effects of the two (Minshall 1984). An experimental approach looking at the colonization of spaces under simple and complex substrates by aquatic organisms in each habitat would help to evaluate the effects of habitat-mediated substrate complexity on the colonization of aquatic organisms (Schmude et al. 1998).

This study aimed to evaluate the effects of interstitial space between substrate particles, as an indicator of substrate complexity, on the colonization of aquatic organisms using an experimental approach employing both pool and riffle channel unit habitats in a temperate stream.

\section{Materials and methods}

Field experiments were conducted in the upper reaches of the Fujii River, a temperate mountain stream in eastern Japan $\left(36^{\circ} 27^{\prime} \mathrm{N}, 140^{\circ} 16^{\prime} \mathrm{E}\right)$. The stream width and channel gradient at the study site averaged $1.8 \mathrm{~m}$ and $0.7 \%$, respectively. Two types of channel unit habitats were present: riffles and pools (Frissell et al. 1986). Riffle lengths were typically short (mean 8 m; SD 5.7). Using the Wentworth classification (Bain 1999), the dominant types of substrate in each channel unit were assessed visually. The streambed was composed mainly of pebbles, cobbles, and boulders in the riffles, and sand, silt, and small patches of cobbles in the pools.

Field experiments were replicated five times from July 9 to September 3, 2004, and replicates were divided into early (from July 9 to July 30, $n=3$ ) and late (from August 15 to September 3, $n=2$ ) periods. To examine the effects of habitat-mediated substrate complexity on aquatic insect colonization, we set three types of substrate conditions in the center of each riffle or pool: (1) a single cobble was laid (C), (2) gravel (ca. $4 \mathrm{~mm}$ in diameter) was laid in a single layer (G), and (3) a single cobble was laid on gravel (GC). The potentially available habitat area for aquatic organisms on the surface and back surface of the single cobble was nearly equal between the $\mathrm{C}$ and GC substrates, but the GC substrate had interstitial spaces between the gravel and cobble. Substrate particles for use in each experiment were picked up from adjacent downstream reaches of the study site. Before starting each experiment, the surface of the cobbles and gravels was scoured with a brush to wash away biofilms (e.g., filamentous algae, cyanobacteria, diatoms, actinomycete or hyphomycete fungi, and detrital and silt particles) enmeshed in a gelatinous polysaccharide matrix on the surface of the substrates, which appear to be major transducers of energy and matter in lotic ecosystems (Giller and Malmqvist 1998).

Current velocities were measured to the nearest $5 \mathrm{~cm} / \mathrm{s}$ at the surface using a float, and were found to be significantly different between riffle and pool (range $40.0-55.0 \mathrm{~cm} / \mathrm{s}, n=5$, pool: range $10.0-20.0 \mathrm{~cm} / \mathrm{s}$, $n=5$, Mann-Whitney $U$ test, $p=0.009)$. Water depth was measured to the nearest $1 \mathrm{~cm}$ with a ruler and were significantly different between riffle (range $12.0-21.0 \mathrm{~cm} / \mathrm{s}, n=5$ ) and pool (range 24.0-33.0 cm/s, $n=5$, Mann-Whitney $U$ test, $p=0.008$ ). The maximum diameter of cobble used in the experiments (range 9.5-9.8 cm, $n=80$ ) was not significantly different between the two channel unit habitats and between the two substrates incorporating cobbles (two-way ANOVA, habitat: $F_{1,76 d f}=0.20, p=0.65$; substrate: $F_{1,76 d f}=1.46$, $p=0.23$; and interaction: $\left.F_{1,76 d f}=0.0005, p=0.76\right)$.

A plastic cage $(10 \mathrm{~cm} \times 20 \mathrm{~cm} \times 5 \mathrm{~cm}$, mesh size: $5 \mathrm{~mm})$ was divided into four compartments $(10 \mathrm{~cm} \times 5 \mathrm{~cm} \times 5 \mathrm{~cm}$; each compartment was separated by a $5 \mathrm{~mm}$ mesh) which were set for each habitat and substrate during the day. The top side of every cage was kept open to allow access of predators such as 
insectivorous benthic fish (Japanese fluvial sculpin, Cottus pollux), that numerically dominated the fish assemblage in the study area (Natsumeda 2007). Each compartment within a cage was filled with the same substrate. A preliminary study indicated that a single week was an appropriate time frame to allow for the colonization of aquatic organisms in the study area (Natsumeda, unpublished data). Three cages with different substrates were lowered to the bottom of each channel unit habitat at $1 \mathrm{~m}$ apart. Water temperature was measured at the start of each day and ranged from 21.8 to $26.8^{\circ} \mathrm{C}$. After 1 week, each cage was carefully brought to the surface and all collected aquatic organisms from each compartment of a cage were preserved in $10 \%$ formalin solution. The collected aquatic organisms were identified under a binocular microscope to the lowest possible taxon, according to Kawai and Tanida (1985), and the number of specimens and wet weight (measured to the nearest $1 \mathrm{mg}$ ) at the family level were recorded for each cage (data for the four compartments in each cage were pooled).

To illustrate the habitat-mediated effects of interstitial spaces between substrates on the colonization of aquatic organisms, taking into account the effect of temporal variation (Mackay 1992), three-way ANOVA (factor = habitats, substrate, and periods) tests for multiple comparisons of the number of specimens, wet weight, Shannon-Wiener's diversity index ( $H^{\prime}$ : Kikkawa and Anderson 1986), taxonomic richness, and evenness (at the family level) were used. The number of specimens and wet weights of individual taxa were also tested using three-way ANOVA (factor = habitats, substrate, and periods), but taxon-specific analyses were limited to the three most abundant taxa; the number of specimens of each taxon accounted for over 10\% of the total number of specimens. Before the analysis, data for the number of specimen and wet weight of aquatic insects were transformed on the $\log _{10}$ scale to approximate normality, and homogeneity of variances was checked.

\section{Results}

In total, 405 and 108 aquatic organisms (both from 13 families) were identified in the experiments in the riffle and pool, respectively (Table 1). Of these, hydropsychid larvae dominated in both the abundance and wet weight in every substrate in the riffle, and chironomid larvae dominated in the abundance in every substrate in both the riffle and pool (Tables 1,2).

The aquatic organism abundance (individuals/cage) in the experiments was significantly different between habitats and among the three substrates [three-way ANOVA, habitat: riffle $=26.3 \pm 15.1 \mathrm{SD}, n=15$, pool $=7.3 \pm 5.4 \mathrm{SD}, n=15, F_{1,18 d f}=24.07, p<0.001$; substrate: a single cobble $(\mathrm{C})=9.2 \pm 7.2 \mathrm{SD}$, $n=10$, gravel $(\mathrm{G})=16.2 \pm 12.2 \mathrm{SD}, n=10$, a single cobble on gravel $(\mathrm{GC})=24.9 \pm 19.1 \mathrm{SD}, n=10$, $F_{2,18 d f}=5.01, p=0.019$; and period: early $=15.6 \pm 13.3 \mathrm{SD}, n=18$, late $=18.5 \pm 17.3 \mathrm{SD}, n=12$, $\left.F_{1,18 d f}=0.35, p=0.56\right]$, with no significant interaction effects (habitat $\times$ substrate: $F_{2,18 d f}=0.55, p=0.58$; habitat $\times$ period: $F_{1,18 d f}=0.28, p=0.61$; substrate $\times$ period: $F_{2,18 d f}=0.82, p=0.46$; and habitat $\times$ substrate $\times$ period: $F_{2,18 d f}=0.80, p=0.46$; Figs. 1a, 2a, 3a). Post hoc tests indicated significant differences in the abundance of aquatic organisms between the $\mathrm{C}$ and GC substrates (Bonferroni test, $p=0.024$, Fig. 2a).

The wet weight of aquatic organisms (g/cage) in the experiments was significantly different between habitats and among the three substrates (three-way ANOVA, habitat: riffle $=0.08 \pm 0.06 \mathrm{SD}, n=15$, pool $=0.02 \pm 0.02 \mathrm{SD}, n=15, F_{1,18 d f}=28.05, p<0.001 ;$ substrate: $\mathrm{C}=0.02 \pm 0.02 \mathrm{SD}, n=10$, $\mathrm{G}=0.04 \pm 0.03 \mathrm{SD}, n=10, \mathrm{GC}=0.08 \pm 0.07 \mathrm{SD}, n=10, F_{2,18 d f}=4.86, p=0.021$; and period: early $=$ $0.05 \pm 0.05 \mathrm{SD}, n=18$, late $=0.04 \pm 0.06 \mathrm{SD}, n=12, F_{1,18 d f}=0.55, p=0.47$ ), with no significant interaction effects (habitat $\times$ substrate: $F_{2,18 d f}=2.12, p=0.15$; habitat $\times$ period: $F_{1,18 d f}=2.11, p=0.16$; substrate $\times$ period: $F_{2,18 d f}=0.19, p=0.82$; and habitat $\times$ substrate $\times$ period: $F_{2,18 d f}=1.09, p=0.36$; Figs. 1b, 2b, 3b). Post hoc tests indicated significant differences in the wet weight of aquatic organisms between the $\mathrm{C}$ and GC substrates (Bonferroni test, $p=0.021$, Fig. 2b).

The diversity index $\left(H^{\prime}\right)$ of aquatic organisms (/cage) in the experiments was significantly different between habitats (three-way ANOVA, riffle $=1.08 \pm 0.27 \mathrm{SD}, n=15$; and pool $=0.61 \pm 0.54 \mathrm{SD}, n=15, F_{1,18 d f-}$ $=14.69, p=0.001$ ) and between periods (early $=1.02 \pm 0.41 \mathrm{SD}, n=18$; and late $=0.57 \pm 0.48 \mathrm{SD}$, $\left.n=12, F_{1,18 d f}=11.05, p=0.004\right)$, but $H^{\prime}$ was not significantly different among the three substrates $\left(\mathrm{C}=0.76 \pm 0.48 \mathrm{SD}, n=10 ; \mathrm{G}=0.72 \pm 0.55 \mathrm{SD}, n=10 ;\right.$ and $\mathrm{GC}=1.04 \pm 0.38 \mathrm{SD}, n=10, F_{2,18}=2.45$, $p=0.11$ ), with no significant interaction effects (habitat $\times$ substrate: $F_{2,18 d f}=0.29, \quad p=0.75$; 
Table 1 Numerical abundance $(n)$ and percentage of aquatic organisms sampled $\left(0.02 \mathrm{~m}^{2} \times 5\right.$ replicates $)$ using three types of substrate in a riffle and pool of a temperate stream, Japan

\begin{tabular}{|c|c|c|c|c|c|c|c|c|c|c|c|c|}
\hline \multirow[t]{4}{*}{ Aquatic organisms } & \multicolumn{12}{|c|}{ Substrate } \\
\hline & \multicolumn{6}{|c|}{ Riffle } & \multicolumn{6}{|c|}{ Pool } \\
\hline & \multicolumn{2}{|l|}{ G } & \multicolumn{2}{|l|}{$\mathrm{C}$} & \multicolumn{2}{|l|}{ GC } & \multicolumn{2}{|l|}{ G } & \multicolumn{2}{|l|}{$\mathrm{C}$} & \multicolumn{2}{|c|}{ GC } \\
\hline & $n$ & $\%$ & $n$ & $\%$ & $n$ & $\%$ & $n$ & $\%$ & $n$ & $\%$ & $n$ & $\%$ \\
\hline \multicolumn{13}{|l|}{ Ephemeroptera } \\
\hline Heptageniidae & 0 & 0.0 & 2 & 3.2 & 3 & 1.4 & 4 & 12.9 & 0 & 0.0 & 3 & 6.1 \\
\hline Baetidae & 10 & 7.8 & 6 & 9.5 & 18 & 8.5 & 4 & 12.9 & 5 & 17.9 & 9 & 18.4 \\
\hline Ephemerellidae & 2 & 1.6 & 0 & 0.0 & 2 & 0.9 & 1 & 3.2 & 1 & 3.6 & 0 & 0.0 \\
\hline \multicolumn{13}{|l|}{ Coleortera } \\
\hline Psephenidae & 0 & 0.0 & 0 & 0.0 & 1 & 0.5 & 0 & 0.0 & 0 & 0.0 & 0 & 0.0 \\
\hline \multicolumn{13}{|l|}{ Diptera } \\
\hline Tipulidae & 0 & 0.0 & 0 & 0.0 & 3 & 1.4 & 0 & 0.0 & 0 & 0.0 & 1 & 2.0 \\
\hline Chironomidae & 44 & 34.1 & 25 & 39.7 & 72 & 33.8 & 16 & 51.6 & 9 & 32.1 & 29 & 59.2 \\
\hline Simuliidae & 1 & 0.8 & 0 & 0.0 & 0 & 0.0 & 0 & 0.0 & 0 & 0.0 & 0 & 0.0 \\
\hline \multicolumn{13}{|l|}{ Trichoptera } \\
\hline Hydropsychidae & 65 & 50.4 & 26 & 41.3 & 102 & 47.9 & 4 & 12.9 & 8 & 28.6 & 7 & 14.3 \\
\hline Stenopsychidae & 2 & 1.6 & 3 & 4.8 & 8 & 3.8 & 2 & 6.5 & 5 & 17.9 & 0 & 0.0 \\
\hline Hydroptilidae & 1 & 0.8 & 0 & 0.0 & 0 & 0.0 & 0 & 0.0 & 0 & 0.0 & 0 & 0.0 \\
\hline Glossosomatidae & 2 & 1.6 & 0 & 0.0 & 3 & 1.4 & 0 & 0.0 & 0 & 0.0 & 0 & 0.0 \\
\hline Goeridae & 2 & 1.6 & 0 & 0.0 & 1 & 0.5 & 0 & 0.0 & 0 & 0.0 & 0 & 0.0 \\
\hline \multicolumn{13}{|l|}{ Oligochaeta } \\
\hline Tubificidae & 0 & 0.0 & 1 & 1.6 & 0 & 0.0 & 0 & 0.0 & 0 & 0.0 & 0 & 0.0 \\
\hline Total & 129 & 100.0 & 63 & 100.0 & 213 & 100.0 & 31 & 100.0 & 28 & 100.0 & 49 & 100.0 \\
\hline
\end{tabular}

Percentages of taxa that shared more than $30.0 \%$ in each location are expressed as bold type

$G$ gravel, $C$ a single cobble, $G C$ a single cobble on gravel

habitat $\times$ period: $F_{1,18 d f}=3.50, p=0.08$; substrate $\times$ period: $F_{2,18 d f}=0.29, p=0.75$; and habitat $\times$ substrate $\times$ period: $F_{2,18 d f}=0.24, p=0.79$; Figs. $1 \mathrm{c}, 2 \mathrm{c}, 3 \mathrm{c}$ ).

The taxonomic richness of aquatic organisms (/cage) in the experiments was significantly different between habitats, among the three substrates, and between periods (three-way ANOVA, habitat: riffle $=4.47 \pm 1.89$ $\mathrm{SD}, n=15$; and pool $=2.40 \pm 1.40 \mathrm{SD}, n=15, F_{1,18 d f}=15.55, p<0.001$. Substrate: $\mathrm{C}=2.60 \pm 1.27 \mathrm{SD}$, $n=10 ; \mathrm{G}=3.20 \pm 2.15 \mathrm{SD}, n=10$; and $\mathrm{GC}=4.50 \pm 1.96 \mathrm{SD}, n=10, F_{2,18 d f}=4.61, p=0.024$. Periods: early $=4.00 \pm 1.94 \mathrm{SD}, n=18$; and late $=2.58 \pm 1.68 \mathrm{SD}, n=12, F_{1,18 d f}=7.19, p=0.015$ ), with no significant interaction effects (habitat $\times$ substrate: $F_{2,18 d f}=1.29, p=0.30$; habitat $\times$ period: $F_{1,18 d f}=0.02$, $p=0.88$, substrate $\times$ period: $F_{2,18 d f}=0.03, p=0.97$; and habitat $\times$ substrate $\times$ period: $F_{2,18 d f}=0.30$, $p=0.75$; Figs. 1d, 2d, 3d). Post hoc tests indicated significant differences in the taxonomic richness of aquatic organisms between the $\mathrm{C}$ and GC substrates (Bonferroni test, $p=0.023$, Fig. 2d).

The evenness of aquatic organisms (/cage) in the experiments was significantly different between habitats (two-way ANOVA, riffle $=0.80 \pm 0.14 \mathrm{SD}, n=15$; and pool $=0.56 \pm 0.42 \mathrm{SD}, n=15, F_{1,18 d f}=18.18$, $p<0.001$ ) and between periods (early $=0.79 \pm 0.23 \mathrm{SD}, n=18$; and late $=0.52 \pm 0.40 \mathrm{SD}, n=12$, $\left.F_{1,18 d f}=14.43, p=0.001\right)$ with a significant interaction effect between habitat and period $\left(F_{1,18 d f}=19.55\right.$, $p<0.001)$, but evenness was not significantly different among the three substrates $(\mathrm{C}=0.73 \pm 0.39 \mathrm{SD}$, $n=10 ; \mathrm{G}=0.57 \pm 0.41 \mathrm{SD}, n=10$; and $\mathrm{GC}=0.75 \pm 0.13 \mathrm{SD}, n=10, F_{2,18 d f}=2.36, p=0.12$. Interaction, habitat $\times$ substrate: $F_{2,18 d f}=6.46, p=0.008$; substrate $\times$ period: $F_{2,18 d f}=1.66, p=0.22$; and habitat $\times$ substrate $\times$ period: $F_{2,18 d f}=1.49, p=0.25$; Figs. 1e, 2e, 3e). Simple main effect tests of the period in each habitat indicated a significant effect of period on the evenness in the pool $\left(F_{1,18 d f}=33.79, p<0.001\right)$.

The three most abundant aquatic organism taxa were Hydropsychidae (41.3\%), Chironomidae (38.0\%) and Baetidae (10.1\%). In hydrophychid larvae, the two main effects (habitat and substrate) had significant effects 
Table 2 Wet weight $[W(\mathrm{~g})]$ and percentage of aquatic organisms sampled $\left(0.02 \mathrm{~m}^{2} \times 5\right.$ replicates $)$ using three types of substrate in a riffle and pool of a temperate stream, Japan

\begin{tabular}{|c|c|c|c|c|c|c|c|c|c|c|c|c|}
\hline \multirow[t]{4}{*}{ Aquatic organisms } & \multicolumn{12}{|c|}{ Substrate } \\
\hline & \multicolumn{6}{|l|}{ Riffle } & \multicolumn{6}{|l|}{ Pool } \\
\hline & \multicolumn{2}{|l|}{$\mathrm{G}$} & \multicolumn{2}{|l|}{$\mathrm{C}$} & \multicolumn{2}{|l|}{ GC } & \multicolumn{2}{|l|}{$\mathrm{G}$} & \multicolumn{2}{|l|}{$\mathrm{C}$} & \multicolumn{2}{|l|}{ GC } \\
\hline & $W$ & $\%$ & $W$ & $\%$ & $W$ & $\%$ & $W$ & $\%$ & $W$ & $\%$ & $W$ & $\%$ \\
\hline \multicolumn{13}{|l|}{ Ephemeroptera } \\
\hline Heptageniidae & 0 & 0.0 & 0.005 & 4.6 & 0.023 & 2.6 & 0.03 & 42.1 & 0 & 0.0 & 0.02 & 27.8 \\
\hline Baetidae & 0.014 & 4.5 & 0.006 & 5.1 & 0.027 & 3.1 & 0.01 & 13.2 & 0.012 & 16.2 & 0.012 & 16.0 \\
\hline Ephemerellidae & 0.004 & 1.3 & 0 & 0.0 & 0.011 & 1.2 & 0.002 & 2.6 & 0.002 & 2.7 & 0 & 0.0 \\
\hline \multicolumn{13}{|l|}{ Coleortera } \\
\hline Psephenidae & 0 & 0.0 & 0 & 0.0 & 0.05 & 5.7 & 0 & 0.0 & 0 & 0.0 & 0 & 0.0 \\
\hline \multicolumn{13}{|l|}{ Diptera } \\
\hline Tipulidae & 0 & 0.0 & 0 & 0.0 & 0.008 & 0.9 & 0 & 0.0 & 0 & 0.0 & 0.006 & 8.3 \\
\hline Chironomidae & 0.032 & 10.4 & 0.016 & 14.4 & 0.059 & 6.7 & 0.015 & 19.7 & 0.008 & 10.8 & 0.02 & 31.3 \\
\hline Simuliidae & 0.003 & 1.0 & 0 & 0.0 & 0 & 0.0 & 0 & 0.0 & 0 & 0.0 & 0 & 0.0 \\
\hline \multicolumn{13}{|l|}{ Trichoptera } \\
\hline Hydropsychidae & 0.223 & 72.4 & 0.08 & 69.4 & 0.36 & 40.3 & 0.012 & 15.8 & 0.02 & 32.4 & 0.012 & 16.7 \\
\hline Stenopsychidae & 0.009 & 2.9 & 0.006 & 5.6 & 0.147 & 16.7 & 0.005 & 6.6 & $\mathbf{0 . 0 3}$ & 37.8 & 0 & 0.0 \\
\hline Hydroptilidae & 0.003 & 1.0 & 0 & 0.0 & 0 & 0.0 & 0 & 0.0 & 0 & 0.0 & 0 & 0.0 \\
\hline Glossosomatidae & 0.001 & 0.3 & 0 & 0.0 & 0.182 & 20.6 & 0 & 0.0 & 0 & 0.0 & 0 & 0.0 \\
\hline Goeridae & 0.019 & 6.2 & 0 & 0.0 & 0.02 & 2.3 & 0 & 0.0 & 0 & 0.0 & 0 & 0.0 \\
\hline \multicolumn{13}{|l|}{ Oligochaeta } \\
\hline Tubificidae & 0 & 0.0 & 0.001 & 0.9 & 0 & 0.0 & 0 & 0.0 & 0 & 0.0 & 0 & 0.0 \\
\hline Total & 0.308 & 100.0 & 0.108 & 100.0 & 0.882 & 100.0 & 0.076 & 100.0 & 0.074 & 100.0 & 0.072 & 100.0 \\
\hline
\end{tabular}

Percentages of taxa that shared more than $30.0 \%$ in each location are expressed as bold type

$G$ gravel, $C$ a single cobble, $G C$ a single cobble on gravel

on the larval abundance and wet weight, and there was a significant interaction effect on the larval abundance (habitat $\times$ period) and wet weight (habitat $\times$ substrate), respectively (Table 3). Simple main effect tests of the substrate type in each habitat indicated a significant effect of substrate on the wet weight of hydrophychid larvae in the riffle $\left(F_{2,18 d f}=17.08, p<0.001\right.$; pool: $\left.F_{2,18 d f}=0.03, p=0.98\right)$, and post hoc tests indicated significant differences in larval abundance between the $\mathrm{C}$ and GC substrates (Bonferroni test, $p=0.039$ ), as well as significant differences in the larval wet weight for all possible paired comparisons of substrates in the riffle (Bonferroni test, $\mathrm{C}$ vs. GC: $p<0.001$; G vs. GC: $p=0.021$; and $\mathrm{G}$ vs. $\mathrm{C}: p=0.035$ ). In chironomid larvae, all three main effects had significant effects on the larval abundance and wet weight, with no significant interaction effects (Table 3). Post hoc tests indicated significant differences in the abundance and wet weight of chironomid larvae between the $\mathrm{C}$ and GC substrates (Bonferroni test, abundance: $p=0.028$; wet weight: $p=0.028$ ). In baetid larvae, only a single main effect (habitat) had a significant effect on the larval abundance, with no significant interaction effects (Table 3).

\section{Discussion}

The results indicated that riffles had a greater abundance and wet weight of aquatic organisms than did pools (Fig. 1), in accordance with the results of previous studies in gravel streams (Hynes 1970; Logan and Brooker 1983; Brown and Brussock 1991; Scealy et al. 2007). Of the 13 families of aquatic organisms identified in this study, hydropsychid larvae dominated in terms of the abundance and wet weight of aquatic insects in the riffle. Hydropsychid larvae are characterized as suspension (filter) feeders in lotic ecosystems (Cummins and Merritt 1996) and respond rapidly to changes in current velocities, with the proportion of net-spinning larvae 
Fig. 1 Comparison of the numerical abundance (a), wet weight (b), diversity index (c), taxonomic richness (d), and evenness (e) of aquatic organisms colonizing a cage (/ $0.02 \mathrm{~m}^{2} \times 5$ replicates) in a riffle (left) and pool (right) of a temperate stream, Japan.

Error bars indicate standard error (SE), and horizontal lines with asterisks indicate significant differences $(* p<0.05$, $* * p<0.01, * * * p<0.001)$
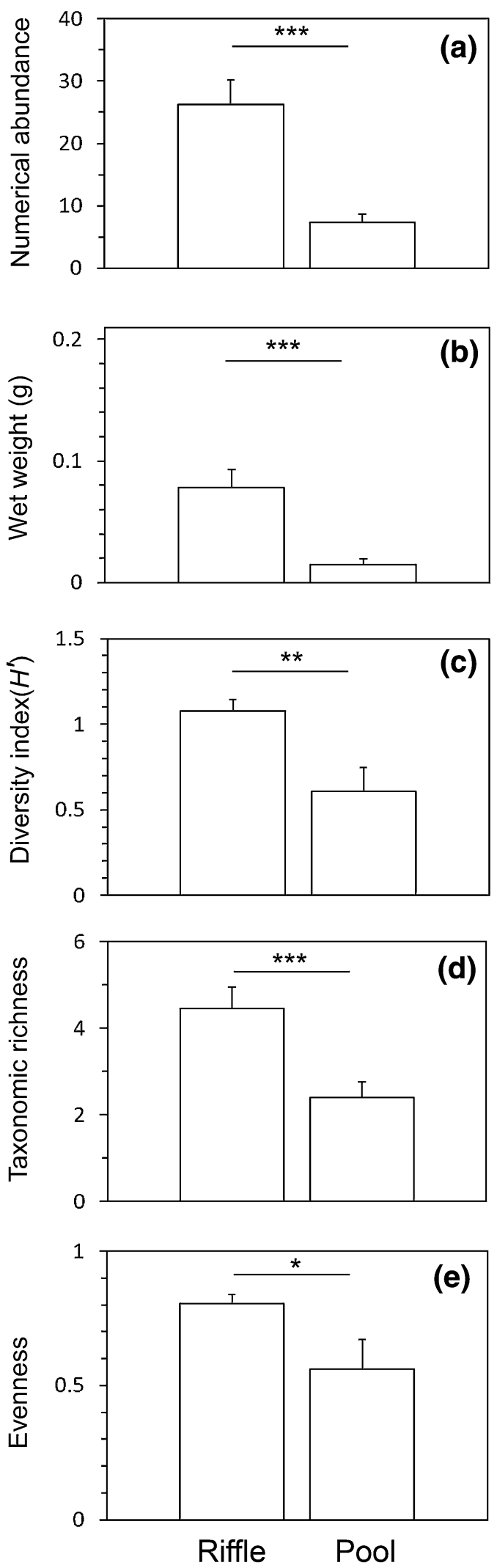

decreasing with decreasing current velocity (Edington 1965; Wallace and Merritt 1980). An experimental study using a semi-artificial system also indicated that channels with faster current velocities resulted in a greater colonization of filter feeders (Simuliidae and Hydrophychidae) than channels with slower current 
Fig. 2 Comparison of the numerical abundance (a), wet weight (b), diversity index (c), taxonomic richness (d), and evenness (e) of aquatic organisms colonizing a cage (/ $0.02 \mathrm{~m}^{2} \times 5$ replicates) with three substrates [empty square: gravel $(\mathrm{G})$, diagonally crossed square: a cobble (C), filled square: a cobble on gravel (GC)] of a temperate stream, Japan. Error bars indicate standard error (SE), and horizontal lines in figures indicate significantly different $(p<0.05)$ substrates determined by Bonferroni correction
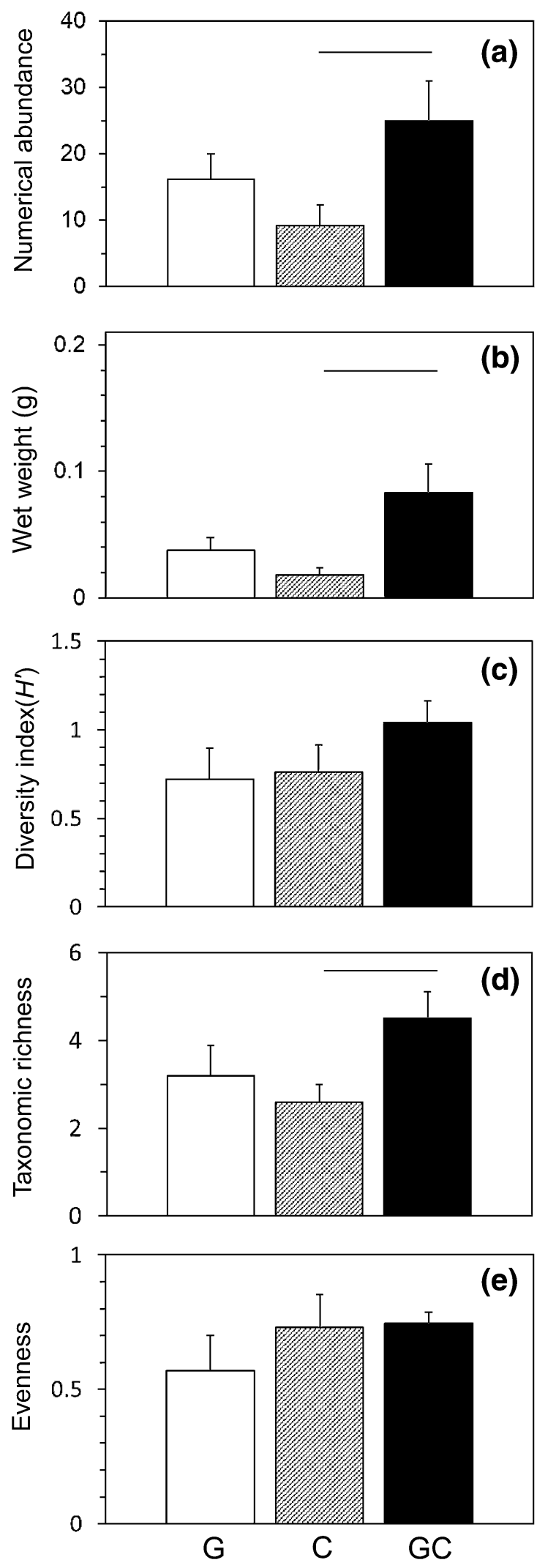
Fig. 3 Comparison of the numerical abundance (a), wet weight (b), diversity index (c), taxonomic richness (d), and evenness (e) of aquatic organisms colonizing a cage (/ $0.02 \mathrm{~m}^{2} \times 5$ replicates) in early (left) and late (right) periods during the study of a temperate stream, Japan. Error bars indicate standard error (SE), and horizontal lines with asterisks indicate significant differences $(* p<0.05$, $* * p<0.01)$
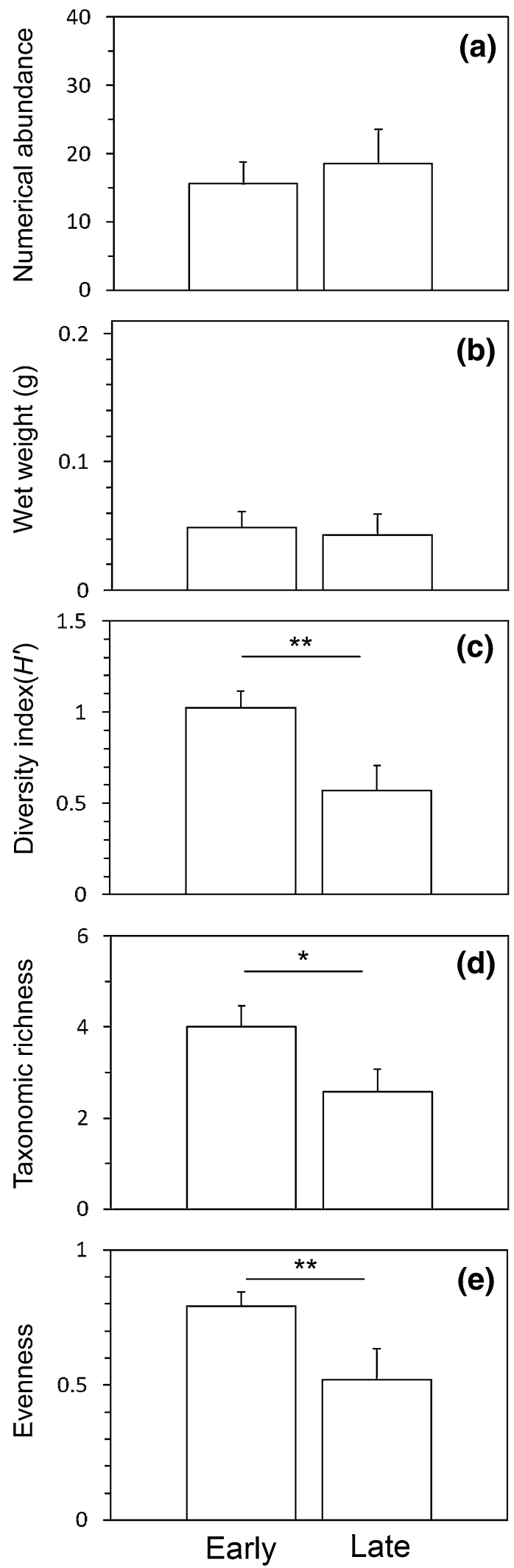


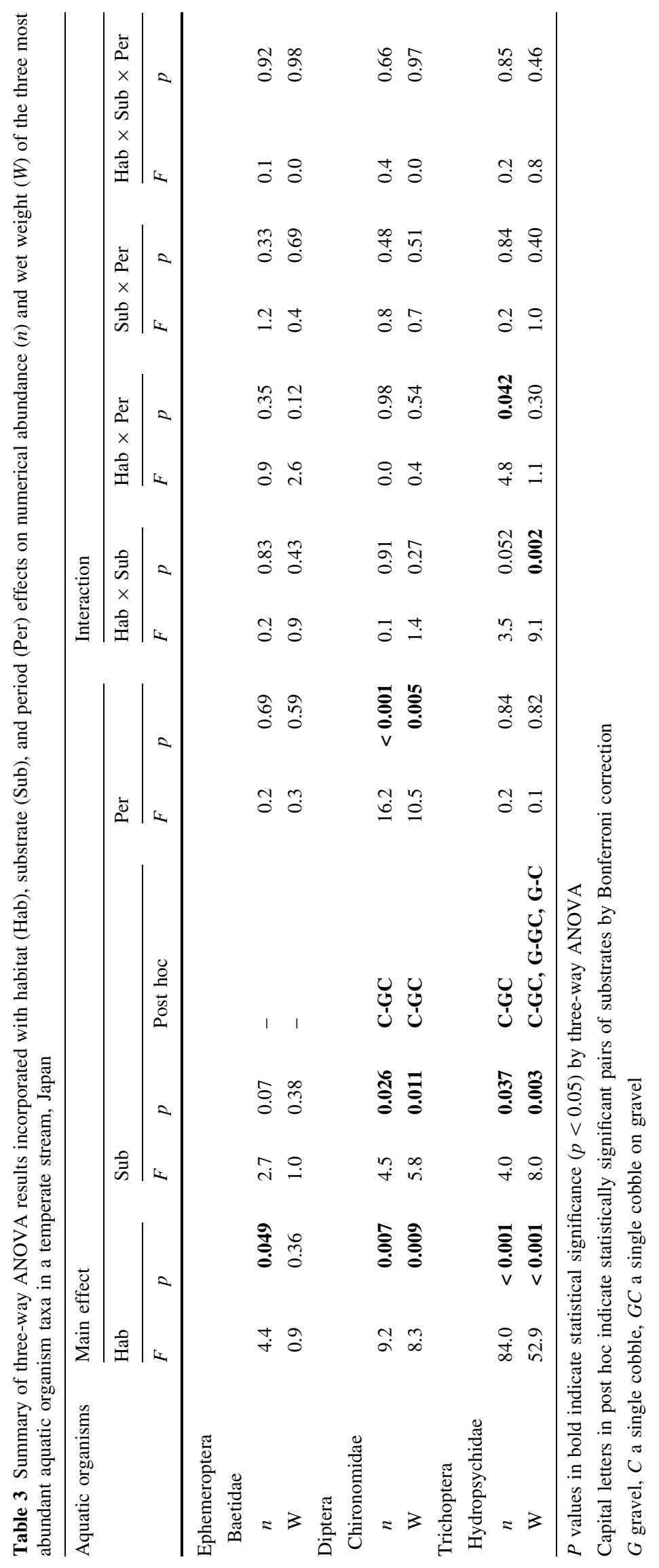


velocities (Ciutti et al. 2004). Riffles with faster current velocities are expected to facilitate the colonization of such filter feeders by offering greater access to suspended particles in running water (Georgian and Thorp 1992; Closs et al. 2004).

Our results also indicate the significant effect of temporal variation (early and late period) on the diversity index $\left(H^{\prime}\right)$, taxonomic richness, and evenness of aquatic organisms (Fig. 3); these measures declined with time over more than 2 months in summer (from July to early September). Biological diversity comprises taxonomic richness and evenness: the number of taxa in a community and how similar taxa are in their abundances, respectively (Maguran 2004). Evenness may have a strong impact on local and regional ecosystem functioning (Hillebrand et al. 2008), and meta-analysis suggests that evenness should be explicitly considered given that it may reflect unique aspects of diversity in aquatic ecosystems (Soininen et al. 2012). The results of simple main effect tests of period in each habitat indicated a significant effect of the period on evenness in the pool, suggesting the possibility of a particular taxon (i.e., Chironomidae) being dominated over time in pools, rather than in riffles. This implies the importance of habitat-specific differences in the evenness of aquatic organisms that reflect the colonization dynamics of dominant taxa over time (McCulloch 1986; Mackay 1992).

Substrate had significant effects on the abundance, wet weight, and taxonomic richness of aquatic organisms in this study, and post hoc tests indicated significant differences between the C and GC substrates (Fig. 2). Any substrates immerged in water will soon be colonized by microbes and biofilm and develop biofouling assemblages, which play important roles in organic matter remineralization, nutrient regeneration and element cycling, contaminant concentration, the transference of energy through food webs, and the induction of benthic invertebrate larval settlement (Dang and Lovell 2016). Consequently, biofilm is of ecological relevance for larval aquatic organisms, not only as a food source but also as an important factor to enhance their ability to attach to the substrate in stream habitats (Ditsche et al. 2014). These findings suggest the importance of interstitial space between substrates (e.g., gravel, a single cobble on gravel) covered by biofilm in allowing colonization by aquatic organisms (Minshall 1984; Ciutti et al. 2004; Duan et al. 2008); however, the space underneath a single cobble per se does not provide as many attractive refugia for small aquatic organisms as does gravel (Minshall and Minshall 1977; Mackay 1992). Empirical studies have indicated that colonization by aquatic organisms may depend on the substrate particle size used; small substrates (10-33 mm in diameter) supported more specimens of aquatic organisms than did larger substrates such as cobbles (53-175 mm in diameter, Wise and Molles 1979; Michael and Culver 1987). The interstitial spaces of smaller substrates are not habitable by predators and provide refugia for small aquatic organisms; this may result in a lower mortality via predation (Peckarsky 1982; Michael and Culver 1987).

The substrate had significant effects on larval hydrophychid (abundance and wet weight) filter feeders, and post hoc tests indicated significant differences in the larval abundance and wet weight between the $\mathrm{C}$ and GC substrates (Table 3). Hydropsychid larvae typically reside on the substrate surfaces exposed to the current, but they also build retreats by crawling into interstitial spaces in gravel substrates and cementing the gravel together with their silk, which seems to make them less vulnerable to aquatic predators (Genito and Kerans 1999). As our study design did not eliminate the risk of predation from predators such as stonefly and insectivorous benthic fish at the study site (e.g., Japanese fluvial sculpin, Natsumeda 2007), it is likely that interstitial spaces between cobble and gravel substrates provided structural refugia for hydropsychid larvae against such predators (Michael and Culver 1987; Haro and Brusven 1994).

The results of the study principally support the idea that more complex substrates can provide more refugia, and, therefore, can support a greater variety of aquatic organisms than simple substrates (Allan 1975; Minshall 1984; Way et al. 1995). Moreover, our results also indicated the significant positive effects of interstitial space between streambed materials in riffles on the colonization of aquatic organisms such as net-spinning caddisfly (Hydrophychid) larvae. These larval caddisflies could be expected to increase the stability of benthic substrates against substrate scouring flooding via their filtrating nets binding particles to the streambed (Cardinale et al. 2004; Takao et al. 2006; Nunokawa et al. 2008). Adding natural cobbles onto gravel streambeds in riffles is expected to enhance the availability of spatial refugia (i.e., interstitial space between substrates) for the colonization of net-spinning caddisflies that act as stream ecosystem engineers (Lancaster 2000; Cardinale et al. 2004). 
Acknowledgements The senior author would like to express thanks to Drs. N. Takamura and H. Kato in National Institute for Environmental Studies (NIES) for advice of study design and identification of aquatic organisms. We would like to thank Editage (http://www.editage.jp) for English language editing.

Open Access This article is distributed under the terms of the Creative Commons Attribution 4.0 International License (http:// creativecommons.org/licenses/by/4.0/), which permits unrestricted use, distribution, and reproduction in any medium, provided you give appropriate credit to the original author(s) and the source, provide a link to the Creative Commons license, and indicate if changes were made.

\section{References}

Allan JD (1975) The distributional ecology and diversity of benthic insects in Cement Creek, Colorado. Ecology 56:1040-1053. https://doi.org/10.2307/1936145

Allan JD (1995) Stream ecology—structure and function of running waters. Chapman and Hall, London

Bain MB (1999) Substrate. In: Bain MB, Stevenson NJ (eds) Aquatic habitat assessment: common methods. American Fisheries Society, Bethesda, pp 95-103

Brown AV, Brussock PP (1991) Comparisons of benthic invertebrates between riffles and pools. Hydrobiologia 220:99-108. https://doi.org/10.1007/BF00006542

Cardinale BJ, Gelmann ER, Palmer MA (2004) Net spinning caddisflies as stream ecosystem engineers: the influence of Hydropsyche on benthic substrate stability. Funct Ecol 18:381-387. https://doi.org/10.1111/j.0269-8463.2004.00865.x

Ciutti F, Cappelletti C, Monauni C, Siligardi M (2004) Influence of substrate composition and current velocity on macroinvertebrates in a semi-artificial system. J Freshw Ecol 19:455-460. https://doi.org/10.1080/02705060.2004.9664919

Closs G, Downes BJ, Boulton A (2004) Freshwater ecology—a scientific introduction. Blackwell, Oxford

Cummins KW, Merritt RW (1996) An introduction to the aquatic insects of North America, 3rd edn. Kendall/Hunt, Dubuque

Dang H, Lovell CR (2016) Microbial surface colonization and biofilm development in marine environments. Microbiol Mol Biol Rev 80:91-138. https://doi.org/10.1128/MMBR.00037-15

Ditsche P, Michels J, Kovalev A, Koop J, Gorb S (2014) More than just slippery: the impact of biofilm on the attachment of nonsessile freshwater mayfly larvae. J R Soc Interface 11:20130989. https://doi.org/10.1098/rsif.2013.0989

Downes BJ, Jordan J (1993) Effects of stone topography on abundance of net-spinning caddisfly larvae and arthropod diversity in an upland stream. Hydrobiologia 252:163-174. https://doi.org/10.1007/BF00008153

Duan X, Wang Z, Tian S (2008) Effects of streambed substrate on macroinvertebrate biodiversity. Front Environ Sci Engin China 2:122-128. https://doi.org/10.1007/s11783-008-0023-y

Edington JM (1965) The effect of water flow on populations of net-spinning Trichoptera. Mitt Int Ver Theor Angew Limnol 13:40-48

Erman DC, Erman NA (1984) The response of stream macroinvertebrates to substrate size and heterogeneity. Hydrobiologia 108:75-82. https://doi.org/10.1007/BF00028185

Frissell CA, Liss WJ, Warren CE, Hurley MD (1986) A hierarchical framework for stream habitat classification: viewing streams in a watershed context. Environ Manag 10:199-214. https://doi.org/10.1007/BF01867358

Genito D, Kerans BL (1999) Effects of a diverse prey assemblage on stonefly feeding. J Freshw Ecol 14:219-231. https://doi.org/ $10.1080 / 02705060.1999 .9663673$

Georgian T, Thorp JH (1992) Effects of microhabitat selection on feeding rates of net-spinning caddisfly larvae. Ecology 73:229-240. https://doi.org/10.2307/1938734

Giller PS, Malmqvist B (1998) The biology of streams and rivers. Oxford University Press, Oxford

Hamid SA, Rawi CSM (2011) Influence of substrate embeddedness and canopy cover on the distribution of Ephemeroptera, Plecoptera and Trichoptera (EPT) in tropical rivers. Aquat Insects 33:281-292. https://doi.org/10.1080/01650424.2011. 640940

Haro RJ, Brusven MA (1994) Effects of cobble embeddedness on the micron its distribution of the sculpin Cottus beldingi and its stonefly prey. Great Basin Nat 54:64-70

Hart DD (1978) Diversity in stream insects: regulation by rock size and microspatial complexity. Verh Int Verein Limnol 20:1376-1381. https://doi.org/10.1080/03680770.1977.11896700

Hillebrand H, Bennett DM, Cadotte MW (2008) Consequences of dominance: a review of evenness effects on local and regional ecosystem processes. Ecology 89:1510-1520. https://doi.org/10.1890/07-1053.1

Hynes HBN (1970) The ecology of running waters. University of Toronto Press, Toronto

Kawai T, Tanida K (1985) Aquatic insects of Japan: manual with keys and illustrations. Tokai University Press, Tokyo (in Japanese)

Kikkawa J, Anderson DJ (1986) Community ecology: pattern and process. Blackwell, Oxford

Lancaster J (2000) Geometric scaling of microhabitat patches and their efficacy as refugia during disturbance. J Anim Ecol 69:442-457. https://doi.org/10.1046/j.1365-2656.2000.00407.xw

Logan P, Brooker MP (1983) The microinvertebrate fauna of riffles and pools. Water Res 17:263-270. https://doi.org/10.1016/ 0043-1354(83)90179-3

Mackay RJ (1992) Colonization by lotic macroinvertebrates: a review of processes and patterns. Can J Fish Aquat Sci 49:617-628. https://doi.org/10.1139/f92-071

Maguran AE (2004) Measuring biological diversity, 1st edn. Blackwell, Oxford 
McCulloch DL (1986) Benthic macroinvertebrate distribution in the riffle-pool communities of two Texas streams. Hydrobiologia 135:61-70. https://doi.org/10.1007/BF00006459

Michael DI, Culver DA (1987) Influence of plecopteran and megalopteran predators on Hydropsyche (Trichoptera: Hydropsychidae) microdistribution and behavior. J N Am Benthol Soc 6:46-55. https://doi.org/10.2307/1467523

Minshall GW (1984) Aquatic insect-substratum relations. In: Resh VH, Rosenberg DM (eds) The ecology of aquatic insects. Praeger, New York, pp 358-400

Minshall GW, Minshall JN (1977) Microdistribution of benthic invertebrates in a Rocky Mountain (U.S.A) stream. Hydrobiologia 55:231-249. https://doi.org/10.1007/BF00017555

Natsumeda T (2007) Movement patterns of Japanese fluvial sculpin Cottus pollux in a headwater stream. Trans Am Fish Soc 136:1769-1777. https://doi.org/10.1577/T06-028.1

Nunokawa M, Gomi T, Negishi JN, Nakamura O (2008) A new method to measure substrate coherent strength of Stenopsyche marmorata. Landsc Ecol Eng 4:123-131. https://doi.org/10.1007/s11355-008-0044-5

O'Connor NA (1991) The effects of habitat complexity on the macroinvertebrates colonizing wood substrates in a lowland stream. Oecologia 85:504-512. https://doi.org/10.1007/BF00323762

Peckarsky BL (1982) Aquatic insect predator-prey relations. Bioscience 32:261-266. https://doi.org/10.2307/1308532

Peckarsky BL (1986) Colonization of natural substrates by stream benthos. Can J Aquat Sci 43:700-709. https://doi.org/10.1139/ f86-085

Scealy JA, Mika SJ, Boulton AJ (2007) Aquatic macroinvertebrate communities on wood in an Australian lowland river: experimental assessment of the interactions of habitat, substrate complexity and retained organic matter. Mar Freshw Res 58:153-165. https://doi.org/10.1071/MF06105

Schmude KL, Jennings MJ, Otis KJ, Piette RR (1998) Effects of habitat complexity on macroinvertebrate colonization of artificial substrates in northern temperate lakes. J N Am Benthol Soc 17:73-80. https://doi.org/10.2307/1468052

Soininen JS, Passy S, Hillebrand H (2012) The relationship between species richness and evenness: a meta-analysis of studies across aquatic ecosystems. Oecologia 169:803-809. https://doi.org/10.1007/s00442-011-2236-1

Takao A, Negishi JN, Nunokawa M, Gomi T, Nakahara O (2006) Potential influences of a net-spinning caddisfly (Trichoptera: Stenopsyche marmorata) on stream substratum stability in a heterogeneous field environment. J N Am Benthol Soc 25:545-555. https://doi.org/10.1899/0887-3593(2006)25\%5b545:PIOANC\%5d2.0.CO;2

Vinson MR, Hawkins CP (1998) Biodiversity of stream insects: variation at local, basin, and regional scales. Annu Rev Enromol 43:271-293. https://doi.org/10.1146/annurev.ento.43.1.271

Wallace JB, Merritt RW (1980) Filter-feeding ecology of aquatic insects. Ann Rev Entomol 25:103-132. https://doi.org/10.1146/ annurev.en.25.010180.000535

Ward JV (1992) Aquatic insect ecology. 1. Biology and habitat. Wiley, New York

Way CM, Burky AJ, Bingham CR, Miller AC (1995) Substrate roughness, velocity refuges, and macroinvertebrate abundance on artificial substrates in the lower Mississippi River. J N Am Benthol Soc 14:510-518. https://doi.org/10.2307/1467537

Williams DD, Smith MR (1996) Colonization dynamics of river benthos in response to local changes in bed characteristics. Freshw Biol 36:237-248. https://doi.org/10.1046/j.1365-2427.1996.00084.x

Wise DH, Molles MC Jr (1979) Colonization of artificial substrates by stream insects: influence of substrate size and diversity. Hydrobiologia 65:69-74. https://doi.org/10.1007/BF00032721

\section{Publisher's Note}

Springer Nature remains neutral with regard to jurisdictional claims in published maps and institutional affiliations. 